\title{
PENGEMBANGAN INTENSI BERWIRAUSAHA MELALUI PRAKTIK KEWIRAUSAHAAN PADA SISWA KELAS XI JURUSAN MDB SMK SWASTA AWALUDDIN
}

\author{
Nuraini Asriati ${ }^{1}$, Sandra Fitria Wardani ${ }^{2}$ \\ ${ }^{1}$ Universitas Tanjungpura, Pontianak \\ ${ }^{2}$ Universitas Tanjungpura, Pontianak
}

Email korespondensi : nuraini.asriati@fkip.untan.ac.id

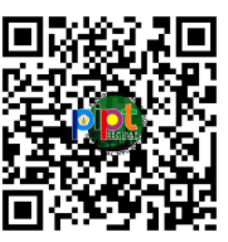

Abstrak

\begin{abstract}
Penelitian ini bertujuan untuk menganalisis bagaimana pengembangan intensi berwirausaha melalui praktik kewirausahaan peserta didik kelas XI Jurusan Manajemen dan Bisnis di SMK Swasta Awaluddin Kecamatan Batu Ampar Kabupaten Kubu Raya. Metode yang digunakan dalam penelitian ini adalah metode kualitatif dengan bentuk penelitian deskriptif. Sumber data dalam penelitian ini adalah guru dan peserta didik SMK Swasta Awaluddin Kecamatan Batu Ampar. Teknik dan alat pengumpulan data yang digunakan dalam penelitian ini adalah pedoman wawancara dan dokumentasi. Indikator intensi berwirausaha adalah dilihat dari kepercayaan diri dan optimisme, berorientasi pada tugas dan hasil, pengambilan resiko, kepemimpinan, cakrawala, dan berorientasi kepada masa depan. Sedangkan praktik kewirausahaan dilihat dari start up business, creativity, opportunity dan risk bearing. Hasil penelitian menunjukkan bahwa praktik kewirausahaan dapat mengembangkan intensi berwirausaha sebesar 85\% di SMK Swasta Awaluddin Kecamatan Batu Ampar, sedangkan intensi berwirausaha dalam menunjukkan rasa percaya diri dan optimisme sangat tinggi untuk setiap peserta didik, berorientasi pada tugas dan hasil juga baik, dimana peserta didik menyelesaikan tugas untuk memperoleh hasil, berani mengambil resiko terlihat pada peserta didik walaupun ada beberapa yang belum berani mengambil resiko, kepemimpinan belum sepenuhnya dimiliki oleh peserta didik, cakrawala sudah terlihat, peserta didik ingin mencoba sesuatu yang baru dan berorientasi masa depan sudah dimiliki peserta didik.
\end{abstract}

Kata kunci: Intensi Berwirausaha, Praktik Kewirausahaan, SMK Swasta Awaluddin

\section{PENDAHULUAN}

Kalimantan Barat memiliki penduduk usia produksi yang sangat tua. Jumlah penduduk yang begitu tinggi berarti pemerintah harus siap bekerja. Dengan pertumbuhan penduduk dan perubahan era industrialisasi, masalah baru juga muncul. Salah satu masalah tersebut adalah habisnya kesempatan kerja. Jumlah pencari kerja (sebagian besar lulusan perguruan tinggi) meningkat, sementara jumlah lapangan kerja yang tersedia semakin berkurang sehingga menyebabkan pengangguran.

Untuk mengatasi masalah pengangguran di Indonesia, salah satu pilihan pemerintah adalah meningkatkan pendidikan, karena melalui pendidikan, orang Indonesia akan memiliki pengetahuan dan keterampilan, dan pengetahuan dan keterampilan tersebut akan digunakan sebagai sarana untuk mengatasi dan mengurangi pengangguran.

Sekolah Menengah Kejuruan (SMK) adalah lembaga pendidikan yang dirancang untuk melatih pekerja terampil dan kemampuan untuk terlibat dalam pekerjaan tertentu di latar depan. Niat dan bakat. Namun, banyak alumni SMK yang masih menganggur, dan memulai bisnis adalah cara terbaik untuk mengurangi pengangguran. Di SMK inilah tempat yang paling cocok bagi siswa yang menimba ilmu di bidang kewirausahaan dan mendapatkan pelatihan langsung praktik bisnis untuk menumbuhkan niat siswa di bidang kewirausahaan.

Menurut Osman (2011, p.36), "Entrepreneurship is the practice of starting new organizationsor revitalizing mature organizations, particulary new businesses generally in response to identified 
opputunities. Arti nya adalah kewirausahaan adalah praktik memulai organisasi baru atau merevitalisasi organisasi dewasa, khususnya bisnis baru secara umum dalam menanggapi peluang yang teridentifikasi.

Pengaplikasian praktik kewirausahaan yang dimaksud tidaklah mudah, karena beberapa tahun terakhir kemampuan peserta didik dalam melakukan praktik kewirausahaan belum mencapai hasil yang sebagaimana diharapkan, seperti beberapa peserta didik telat menyerahkan laporan hasil praktik pemasaran dan pelaksanaan praktik pemasarannnya melewati batas waktu yang telah ditetapkan oleh guru penanggung jawab praktik kewirausahaan tersebut.

Intensi berwirausaha menurut (Yanti Dwi, 2018) merupakan keinginan atau kehendak seseorang melihat kesempatan usaha dan mengambil tindakan untuk menjadikan sebuah karya nyata agar dapat membuat dirinya sukses. Menurut (Larasati, 2016) intensi berwirausaha merupakan kecenderungan hati dengan menimbulkan ketertarikan pada diri seorang dengan kegiatan wirausaha dan keinginan untuk mempelajari lebih lanjut dengan sumber daya dan kesempatan bisnis yang ada untuk memenuhi kebutuhan hidup.

Menurut Abdullah dan Tantri (2016:14) pemasaran adalah "suatu proses sosial dan manajerial dimana individu dan kelompok mendapatkan kebutuhan dan keinginan mereka dengan menciptakan, menawarkan dan bertukar sesuatu yang bernilai satu sama lain. Mursid (2015:26) "pemasaran adalah semua kegiatan usaha yang bertalian dengan arus penyerahan barang dan jasa-jasa dari produsen ke konsumen".

Hal yang membuat peneliti tertarik dalam meneliti di sekolah tersebut adalah, karena disekolah ini diberikan pembekalan tentang ilmu-ilmu mengenai kewirausahaan kepada peserta didik SMK di sekolah. Karena semakin banyak ilmu tentang kewirausahaan yang dimiliki maka akan semakin terbuka wawasan nya tentang kewirausahaan. Praktik kewirausahaan dilakukan dengan memberikan pelatihan kerja di dunia usaha yang dapat bertujuan untuk membekali siswa dalam menguasai ilmu start up dalam memulai usaha, kreativitas dalam memulai usaha, peluang yang ada di dalam usaha, dan resiko yang harus dihadapi di dalam dunia usaha. Sehingga setelah peserta didik menyelesaikan praktik kewirausahaan nya akan muncul intensi dari peserta didik untuk dapat membuka usaha atau berwirausaha seperti usaha ditempat mereka melakukan kegiatan prakteknya.

Praktik kewirausahaan adalah kegiatan yang dilakukan oleh peserta didik kelas XI SMK Swasta Awaluddin Kecamatan Batu Ampar Kabupaten Kubu Raya yang berupa praktik langsung di dunia kerja yang sesuai dengan kompetensi keahlian nya, dimana mereka akan terlatih dilapangan sesuai dengan keahlian nya masing-masing. Kewirausahaan adalah salah satu mata pelajaran yang ada di SMK Swasta Awaluddin Kecamatan Batu Ampar Kabupaten Kubu Raya. Dengan adanya mata pelajaran kewirausahaan, maka dari itu peserta didik bisa menerapkan ilmu yang sudah didapatkan selama proses belajar dan pembelajaran di sekolah. Intensi berwirausaha siswa di dapatkan setelah mereka melaksanakan pekerjaan di lapangan maka akan timbul keinginan, ketertarikan serta ketersediaan untuk bekerja keras atau berkemauan keras untuk berusaha memenuhi kebutuhan hidupnya tanpa merasa takut dengan resiko yang akan terjadi, serta senantiasa belajar dari kegagalan yang dialami. Dikarenakan mereka sudah mendapatkan pengalaman dari praktik kewirausahaan dan ilmu kewirausahaan secara parsial dalam mengembangkan intensi berwirausaha.

Maka dari itu peneliti bermaksud untuk meneliti intensi berwirausaha peserta didik kelas XI Jurusan manajemen dan bisnis setelah mengetahui praktik kewirausahaan. Menurut Peng (2012, p.66), "The Intention of entrepreneurship is one's deterintensiion to be an entrepreneur or to be an entrepreneur who before starting a business (entrepreneurship) requires a strong 
commitment to start it". Artinya, intensi berwirausaha merupakan kebulatan tekad seseorang untuk menjadi seorang wirausaha atau untuk berwirausaha yang sebelum memulai suatu usaha (berwirausaha) dibutuhkan suatu komitment yang kuat.

Penelitian ini sejalan dengan penelitian yang pernah dilakukan oleh Nafisyah (2017, p.96), "Berdasarkan theory of planned behavior latar belakang informasi terdiri dari pengetahuan, media serta intervensi. Pengetahuan dan informasi tentang kewirausahaan dapat diperoleh dari berbagai sumber baik dalam bentuk lisan maupun tulisan. Pengetahuan dan informasi akan mempengaruhi pendangan seseorang terhadap suatu perilaku sehingga pandangan tersebut akan mempengaruhi pembentuk intensi orang yang bersangkutan.

\section{METODOLOGI}

Metode yang digunakan dalam penelitian ini adalah metode kualitatif dengan bentuk penelitian deskriptif. Metode yang digunakan dalam penelitian ini adalah metode deskriptif. Menurut Nawawi (2012, p.56), metode deskriptif adalah "prosedur pemecahan masalah yang diselidiki dengan menggambarkan/ melukiskan keadaan subjek/ objek penelitian (seseorang, lembaga, masyarakat dan lain-lain) pada saat sekarang berdasarkan fakta-fakta yang tampak atau sebagaimana adanya".

Teknik dan alat pengumpulan data menggunakan wawancara dan dokumentasi diuraikan secara deskriptif. Populasi dalam penelitian ini adalah siswa kelas XI Jurusan Manajemen dan Bisnis SMK Swasta Awaluddin Kecamatan Batu Ampar Kabupaten Kubu Raya yang mengikuti kegiatan praktik kewirausahaan. Yang mengikuti praktik kewirausahaan adalah sebanyak 60 siswa terdiri dari kelas Manajemen dan Bisnis kelas A dan B. Pada saat praktik, siswa dibagi menjadi 5 orang dalam 1 kelompok untuk melaksanakan praktik kewirausahaan. Adapun untuk lebih jelasnya populasi dijelaskan pada tabel berikut:
Tabel 1: Populasi

\begin{tabular}{|c|c|c|c|}
\hline No & Kelas & Tempat Praktik & Siswa \\
\hline 1 & \multirow{6}{*}{ XI MDB A } & PT. A & 5 orang \\
\hline 2 & & PT. B & 5 orang \\
\hline 3 & & PT. C & 5 orang \\
\hline 4 & & PT. D & 5 orang \\
\hline 5 & & PT. E & 5 orang \\
\hline 6 & & PT. F & 5 orang \\
\hline 7 & \multirow{6}{*}{ XI MDB B } & PT. 1 & 5 orang \\
\hline 8 & & PT. 2 & 5 orang \\
\hline 9 & & PT. 3 & 5 orang \\
\hline 10 & & PT. 4 & 5 orang \\
\hline 11 & & PT. 5 & 5 orang \\
\hline 12 & & PT. 6 & 5 orang \\
\hline \multicolumn{3}{|c|}{ Total } & 60 orang \\
\hline
\end{tabular}

Sumber: Penulis, 2021

Teknik pengambilan sampel dalam penelitian ini adalah peneliti memilih kelompok 2 kelompok masing-masing kelas yang meraih nilai tertinggi dari tempat praktik kewirausahaan nya. Untuk lebih jelasnya sampel dijelaskan pada tabel berikut:

Tabel 2 : Sampel

\begin{tabular}{|c|c|l|l|}
\hline No & Kelas & Tempat Praktik & \multicolumn{1}{|c|}{ Siswa } \\
\hline 1 & XI MDB A & PT. A & 5 orang \\
\cline { 4 - 4 } 2 & & PT. E & 5 orang \\
\hline 3 & \multirow{2}{*}{ XI MDB B } & PT. 3 & 5 orang \\
\cline { 3 - 4 } 4 & & PT. 4 & 5 orang \\
\hline \multicolumn{2}{|r}{ Total } & 20 orang \\
\hline
\end{tabular}

Sumber: (Penulis, 2021)

Teknik keabsahan yang digunakan adalah teknik triangulasi, dimana pengujian kredibilitas diartikan sebagai pengecekan data dari berbagai sumber dengan berbagai waktu.

\section{HASIL DAN PEMBAHASAN}


Berdasarkan dari hasil wawancara penelitian terhadap peserta didik yang menjadi sampel penelitian, dapat dijelaskan bahwa praktik kewirausahaan di SMK Swasta Awaluddin merupakan implementasi dari teori yang dipelajari, melalui praktik kewirausahaan ini dapat mengembangkan intensi berwirausaha peserta didik. Dari hasil wawancara praktik kepada peserta didik menunjukkan bahwa peserta didik memiliki intensi yang sebesar $85 \%$ untuk berwirausaha, walaupun masih terdapat peserta didik yang belum bisa mengambil risiko, dan berjiwa kepemimpinan.

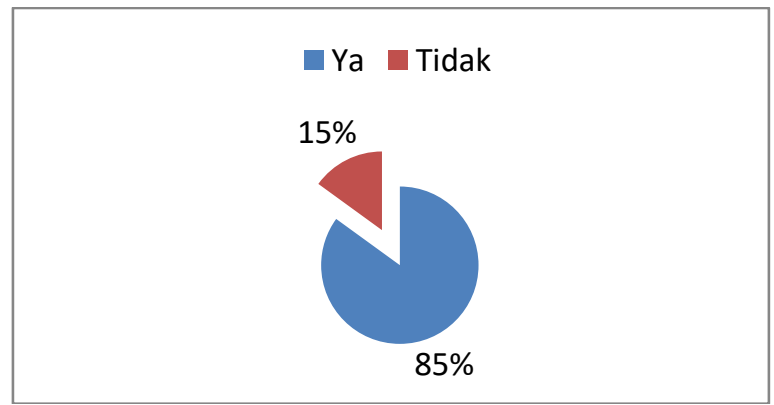

Sumber: (Penulis, 2021)

Gambar 1: Peserta Didik Yang Memiliki Intensi Berwirausaha

\section{Praktik Kewirausahaan}

Berdasarkan hasil wawancara dengan peserta didik indikator 1) Start up, 2) Creativity, 3) Opportunity, 4) Risk Bearing, menunjukkan bahwa praktik kewirausahaan terlaksana dengan baik, dapat dijelaskan pada grafik di bawah ini:

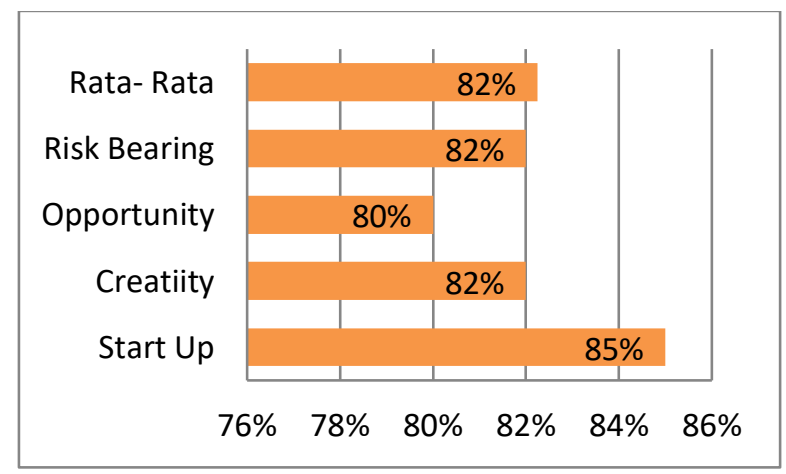

Sumber : (Penulis, 2021)

Gambar 2 : Persentase Indikator Praktik Kewirausahaan
1) Start up, Start Up adalah kemampuan peserta didik dalam memulai usaha dan kemauan dalam memulai usaha, bagaimana rencana dalam membangun usaha yang akan dijalankan, bagaimana membuat manajemen organisasi dalam berwirausaha, rencana dalam mempromosikan usaha agar lebih dikenal. 2) Creativity adalah kemampuan untuk mengerjakan sesuatu yang baru baik itu kreativitas produk ataupun jasa yang akan diperjualkan, 3) Opportunity adalah kemampuan dalam memanfaatkan peluang. Situasi atau kondisi tersebut merupakan peluang atau kesempatan di luar perusahaan atau organisasi yang bisa memberikan peluang untuk berkembang di kemudian hari, 4) Risk bearing adalah kemampuan untuk meman

2) jemen resiko. Semakin tinggi hasil atau laba yang diharapkan dalam suatu usaha maka semakin tinggi tingkat resiko yang harus dihadapi oleh usaha tersebut.

\section{Pengembangan Intensi Berwirausaha}

Berdasarkan hasil wawancara dengan indikator 1) rasa percaya diri dan optimisme, 2) berorientasi pada tugas dan hasil, 3) berani mengambil resiko, 4) kepemimpinan, 5) cakrawala, dan 6) berorientasi pada masadepan dapat dikatakan dapat berkembang dengan baik, seperti dijelaskan pada grafik berikut:

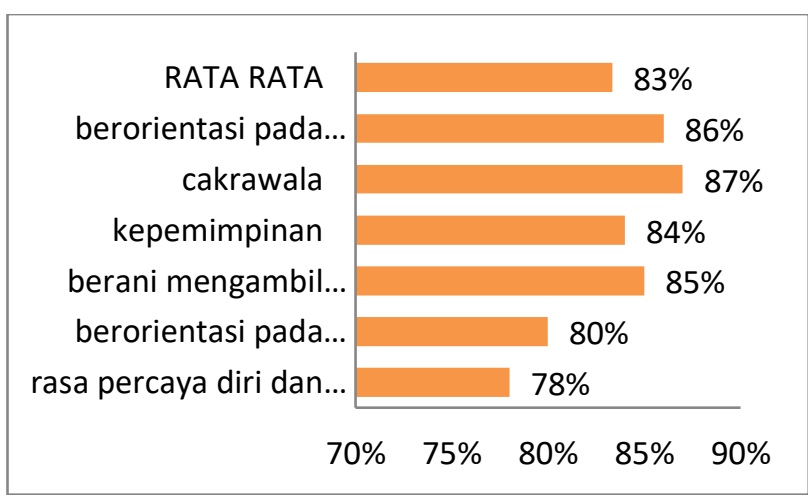

Sumber : (Penulis, 2021) 
Gambar 3 : Persentase Indikator Praktik Kewirausahaan

Pengembangan Intensi berwirausaha melalui praktik kewirausahaan yang ada di SMK Swasta Awaluddin Kecamatan Batu Ampar Kabupaten Kubu Raya adalah; 1) rasa percaya diri dan optimisme merupakan sikap kewirausahawan yang selalu yakin akan kemampuan dirinya sendiri dan selalu berfikir atau beranggapan positif dengan apa yang dilakukannya. Percaya diri dan optimis dari sikap yang positif terhadap kemampuan diri sendiri, walaupun mereka mengetahui kekurangan, tetapi seseorang yang optimis tidak akan berfokus pada kekurangannya, bahkan menutupi kekurangannya dengan sesuatu yang dianggapnya punya kelebihan dibidang lain. Mereka mengembangkan dirinya dengan percaya diri mampu memberikan nilai plus dalam kehidupannya. Berdasarkan hasil wawancara menyatakan bahwa sifat percaya diri dan optimis sudah dimiliki oleh siswa yang dimana mereka dalam mengerjakan tugas/pekerjaan dengan penuh keyakinan untuk memperoleh hasil yang maksimal. Dalam proses pengerjaannya mereka juga selalu optimis dapat menyelesaikannya walaupun banyak kekurangan yang mereka alami karena itu sudah menjadi komitmen mereka untuk memperoleh hasil yang maksimal. Di dalam proses mengerjakan yang sesuai dengan waktu yang sudah ditentukan, siswa mengerjakannya dengan tidak menundanunda waktu sampai batas akhir, siswa melakukannya dengan menentukan waktu yang tepat untuk menyelesaikan tugas/pekerjaan tersebut. Siswa percaya diri dalam mengerjakan dengan tidak bergantung pada orang lain untuk membantunya, siswa memanfaatkan teknologi dalam menyelesaikannya dengan mencari referensi melalui internet dan buku yang sesuai dengan masalahnya.

2) Berorientasi pada tugas dan hasil merupakan salah satu sifat yang harus dimiliki oleh seorang wirausahawan, yang dimana harus memiliki sikap tanggung jawab dan kerja keras pada tugas yang dibebankan kepada mereka sebagai seorang pengusaha. Seorang wirausahawan dalam bergerak selalu mengutamakan pekerjaannya dengan baik, sehingga mendapat hasil yang baik pula dan sangat mengutamakan proses yang ia lakukan dalam menyelesaikan tugas, apakah berjalan dengan efisien atau tidak. Dari hasil penelitian menunjukkan bahwa sikap berorientasi pada tugas sudah dimiliki oleh siswa. Siswa tekun dalam melaksanakan tugas yang diberikan sampai selesai karena sudah menjadi tanggung jawab mereka, sehingga dalam proses pengerjaannya siswa bekerja keras untuk mendapatkan hasil yang mereka inginkan walaupun banyak kesulitan yang mereka temui. Dengan dibantu oleh orang yang berpengalaman dan dengan teknologi seperti media internet siswa dapat menemukan pemecahan masalah yang mereka alami dalam proses pengerjaan tugas tersebut

3) Berani mengambil risiko dan menyukai tantangan adalah hal yang harus diambil oleh seorang wirausahawan untuk mencapai apa yang diinginkannya. Risiko bagi para wirausaha bukanlah sebagai suatu hambatan untuk meraih kesuksesan tetapi dijadikan sebagai suatu tantangan. Wirausaha adalah orang yang lebih menyukai hal-hal yang menantang dalam hidupnya. Dalam pengambilan risiko para wirausaha selalu memperhitungkan matangmatang keputusan yang akan diambil. Dari hasil wawancara, siswa dikatakan berani mengambil risiko dengan melakukan hal yang baru yang belum pernah mereka lakukan sebelumnya. Siswa merasa tertantang untuk melakukannya, karena ingin mengetahui hal yang baru sekaligus untuk menambah pengalaman yang banyak pula. Tetapi ada juga yang tidak merasa tertantang ketika diberikan tugas yang baru dengan alasan karena hal yang baru itu bukanlah sebuah tantangan melainkan sebuah kewajiban yang harus kita hadapi. Sebelum menjalankan suatu pekerjaan/tugas yang baru tentunya kita sudah merencanakan langkah apa yang harus kita lakukan untuk kedepannya. Dengan memperhitungkan langkah sesuai dengan kemampuan yang dimiliki siswa melakukannya mulai dari hal 
yang dasar kemudian naik ke level yang selanjutnya sampai tugas tersebut selesai dan dengan waktu yang sudah ditetapkan. Namun tidak jarang juga ditemukan kegagalan dalam menjalankan pekerjaan itu karena terlalu salah dalam memperhitungkannya dan berambisi untuk mencapai kesuksesan. Tetapi itu bukan lah suatu penghambat melainkan sebuah motivasi untuk kita lebih teliti lagi dalam proses. Siswa merasa kecewa atas kecerobohan yang mereka buat dan akan terus berusaha agar kesalahan tersebut tidak terulang kembali. 5. Bagaimana kepemimpinan dapat menumbuhkan intensi berwirausaha pada siswa kelas XI Jurusan MDB SMK swasta Awaluddin? Kepemimpinan bagi seorang wirausaha adalah modal yang sama pentingnya dengan kepercayaan dan kreatifitas. Menjadi seorang wirausahawan sebenarnya adalah orang yang mampu memimpin diri sendiri dan juga perusahaan tempat iya memimpin para bawahannya. Dari hasil wawancara dikatakan bahwa siswa sudah memiliki jiwajiwa pemimpin untuk kedepanya. Dalam praktik marketing siswa sudah menunjukkan jiwa kepemimpinannya, seperti yang berperan sebagai ketua sudah mampu mengontrol teman kelompoknya. Kemudian yang tidak berperan sebagai ketua juga bisa melaksanakan tugas nya dengan baik walaupun masih terdapat siswa yang sering malas dalam proses mengerjakannya. Dari segi berdiskusi atau bertukar pendapat siswa dapat menghargai teman kelompoknya untuk menyampaikan kritik dan saran mereka masing-masing dan kemudian menyaring hasil dari pendapat tersebut untuk dijadikan sebagai pedoman untuk langkah atau proses selanjutnya. Siswa juga saling berkomunikasi satu sama lain untuk menjalin silahturahmi antar sesama anggota kelompok maupun kelompok lainnya baik itu masalah tugas maupun masalah pribadi dan tidak mengedepankan sikap egoisme di dalam kelompok karena itu dapat menimbulkan konflik dan perselisihan antar kelompok yang akan berdampak bagi semua anggota kelompok dan hasil yang diperoleh tidak akan maksimal.

6) Kepemimpinan bagi seorang wirausaha adalah modal yang sama pentingnya dengan kepercayaan dan kreatifitas. Menjadi seorang wirausahawan sebenarnya adalah orang yang mampu memimpin diri sendiri dan juga perusahaan tempat iya memimpin para bawahannya. Dari hasil wawancara dikatakan bahwa siswa sudah memiliki jiwa-jiwa pemimpin untuk kedepanya. Dalam praktik marketing siswa sudah menunjukkan jiwa kepemimpinannya, seperti yang berperan sebagai ketua sudah mampu mengontrol teman kelompoknya. Kemudian yang tidak berperan sebagai ketua juga bisa melaksanakan tugas nya dengan baik walaupun masih terdapat siswa yang sering malas dalam proses mengerjakannya. Dari segi berdiskusi atau bertukar pendapat siswa dapat menghargai teman kelompoknya untuk menyampaikan kritik dan saran mereka masing-masing dan kemudian menyaring hasil dari pendapat tersebut untuk dijadikan sebagai pedoman untuk langkah atau proses selanjutnya. Siswa juga saling berkomunikasi satu sama lain untuk menjalin silahturahmi antar sesama anggota kelompok maupun kelompok lainnya baik itu masalah tugas maupun masalah pribadi dan tidak mengedepankan sikap egoisme didalam kelompok karena itu dapat menimbulkan konflik dan perselisihan antar kelompok yang akan berdampak bagi semua anggota kelompok dan hasil yang diperoleh tidak akan maksimal.

5) Cakrawala atau keorisinalitasan tentu tidak selalu ada pada diri seseorang. Orisinil dalam bidang kewirausahaan bukan berarti sesuatu yang baru sekali. Akan tetapi produk tersebut mencerminkan hasil kombinasi baru dari komponen-komponen yang sudah ada, sehingga menimbulkan sesuatu yang baru. Dari hasil wawancara menunjukkan bahwa produk yang siswa buat itu bukanlah murni produk yang baru sekali. Siswa menggunakan bahan-bahan yang sama dengan produk pada umumnya, akan tetapi dari segi proses pembuatan dan pengemasan 
siswa melakukannya dengan inovasi baru yang jarang dilihat oleh orang sehingga hasilnya berbeda dengan yang lainnya. Dari hasil wawancara juga menunjukkan bahwa sikap orisinil sudah ada dimiliki oleh siswa tetapi ada juga yang masih belum memiliki sikap tersebut. Pada proses pengerjaan, siswa sudah diberikan tugas masing-masing untuk dikerjakan. Siswa mengerjakannya sesuai tugas yang sudah diberikan dan tidak ikut campur dengan tugas lainnya, akan tetapi banyak siswa yang ingin mencoba atau ikut andil didalam tugas yang bukan menjadi hak mereka dengan alasan tugas yang mereka kerjakan sudah selesai dan ingin menambah wawasan. Nah disitu terletak keorisinilisan siswa yang ingin mencoba semua bidang yang ada didalam kelompok.

6) Berorientasi masa depan merupakan suatu cara pandang/cara pikir seseorang untuk menggapai apa yang ia ingikan kedepannya. Dari hasil wawancara menunjukkan bahwa siswa mempunyai visi untuk kedepannya dengan alasan karena ingin mencapai tujuan mereka masingmasing. Dalam upaya untuk mencapai kesuksesan tersebut tentu tidaklah mudah banyak sekali tantangan yang akan dihadapi kedepannya. Mencari inovasi baru merupakan salah satu langkah untuk mencapai kesuksesan dengan cara mengamati apa yang dibutuhkan oleh lingkungan sekitar dipadukan dengan kemajuan teknologi serta dengan menjalin kerja sama dengan orang banyak. Ketika mencapai suatu kesuksesan siswa merasa puas dengan hasil tersebut karena apa yang mereka inginkan sudah tercapai. Akan tetapi terdapat juga siswa yang kurang puas akan hasil tersebut dengan alasan sifat manusia yang tidak pernah puas akan hasil yang sudah diperoleh sehingga ingin meningkatkannya kelevel yang lebih tinggi lagi. Menyusun perencanaan yang tepat untuk mencapai kesuksesan dengan mempelajari apa yang menjadi prioritas utama dan selalu berkerja keras dalam menjalankannya serta memantau langsung apa yang terjadi di lingkungan sekitar.

\section{KESIMPULAN}

Dari hasil nilai praktik maupun dari pertanyaan yang tanyakan kepada peserta didik menunjukkan bahwa peserta didik memiliki intensi yang sebesar $85 \%$ untuk berwirausaha, walaupun masih terdapat peserta didik yang belum bisa mengambil risiko, dan berjiwa kepemimpinan.

1. Praktik kewirausahaan dilihat dari kemampuan siswa pada saat melaksanakan praktik kewirausahaan di tempat nya masing-masing dan dinilai dengan indikator start up, creativity, opportunity dan risk bearing.

2. Intensi berwirausaha dalam menunjukkan rasa percaya diri dan Optimis yang dimiliki oleh siswa sudah baik, dimana siswa memiliki komitmen dan rasa percaya diri untuk menerima tugas yang diberikan dan selalu optimis dapat mengerjakan tugas tersebut hingga mencapai hasil yang maksimal walaupun sering terdapat tantangan/hambatan yang mereka alami. Berorientasi pada tugas dan hasil pada siswa sudah baik, dimana siswa bertanggung jawab terhadap tugas yang diberikan. Di dalam mengerjakan siswa menemukan kesulitan, akan tetapi siswa tidak putus asa dan selalu bekerja keras dengan mencari dan meminta bantuan dari teman dan guru yang lebih paham serta dengan memanfaatkan teknologi untuk mencapai hasil. Berani mengambil risiko dan menyukai tantangan digemari oleh siswa dengan alasan ingin mendapatkan sesuatu yang baru dan merupakan sebuah kewajiban untuk dilakukan. Dengan memperhitungkan strategi yang matang siswa dapat melakukannya. Terkadang perhitungan itu tidak sejalan dengan tujuan yang diinginkan. Sering kali siswa menemukan masalah dalam proses karena ceroboh, akan tetapi siswa tidak menyerah dan mencari jalan keluar yang baru untuk memecahkan masalah tersebut. Jiwa kepemimpinan sudah dimiliki oleh siswa, dimana siswa 
bertanggung jawab terhadap peran yang iya jalankan walaupun masih ada siswa yang malas dalam menjalankannya. Siswa juga dapat bersosialisasi dengan baik terhadap teman kelompok maupun kelompok lainya dengan saling menghargai kritik dan saran dan tidak mengedepankan egoisme. Keorisinalitasan sudah dimiliki oleh siswa. Siswa membuat produk yang berbeda dengan produk lainnya, dengan bahan yang sama akan tetapi dikombinasikan dengan inovasi yang menarik serta ingin mencoba semua bidang yang bukan menjadi hak mereka dengan alasan menambah wawasan. Selain itu juga terdapat siswa yang belum memiliki keorisinilisan, dimana siswa masih ragu untuk mencoba tugas yang bukan menjadi hak mereka dengan alasan tidak paham akan tugas tersebut.

\section{UCAPAN TERIMA KASIH}

Terima kasih kepada Universitas Tanjungpura (UNTAN), dan seluruh panitia Seminar Nasional PIPT VI 2021 Penerapan Ilmu Pengetahuan Teknologi yang menyelenggarakan seminar dengan tema "Kampus Merdeka Indonesia Jaya".

\section{DAFTAR PUSTAKA}

Abdullah, T. Tantri, F. (2016). Manajemen Pemasaran. Jakarta: Rajagrafindo.

Larasati, D. (2016). Pengaruh Pembelajaran Kewirausahaan Dan
Lingkungan Keluarga Terhadap Intensi Berwirausaha Siswa Kelas Xi Smk N 7 Yogyakarta. Skripsi. UNY. Yogyakarta

Mursid. (2015). Manajemen Pemasaran. Jakarta: Bumi Aksara

Nafisyah, I. (2017). Intensi Berwirausaha Mahasiswa Pendidikan Ekonomi fakultas Ekonomi Universitas Negeri Yogyakartatahun Ajaran 2016/2017. Yogyakarta: Jurnal Ekoonomi dan PendidikanISSN.0287-120.15

Nawawi, H. (2012). Metode Penelitian Bidang Sosial. Jakarta: Gajahmada University Press

Osman, E. (2011). Entrepreneurship, national culture and turkey. Turkey: International Journal of Business and Social Sciencedx.doi.org/12.24883

Peng, Z. (2012). Entrepreneurial Intentions and Its Influencing Factors: A Survey of The University Student in Xi'an China. China:Published Creative Education-

Doi:4236/ce.2012.38b021

Yanti, D. (2018). Studi Komparasi Intensi Berwirausaha Antara Siswa Kelas XI Jurusan Akuntansi Dan Pemasaran Di SMK Negeri 3 Pontianak. Skripsi. UNTAN. Pontianak. 